\title{
RECONSTRUCTING LABOR INCOME SHARES IN ARGENTINA, BRAZIL AND MEXICO, 1870-2000*
}

EWOUT FRANKEMA

Utrecht University $^{\mathrm{a}}$

\begin{abstract}
The labor income share in national income is a good indicator of the extent to which the working classes are able to reap the fruits of economic growth or, conversely, bear the burden of economic stagnation. This paper aims to reconstruct the labor income share of Argentina, Brazil and Mexico in a three-sector framework, including the rural, the urban formal and the urban informal sectors. We find that in all three countries the share of labor earnings peaked in the middle of the $20^{\text {th }}$ century. Fluctuations in the Brazilian and Mexican labor income shares were large, with a sharp decline in the post-1961 and post-1976 periods, respectively. In Argentina, the labor income shares tended to be more constant at levels around 50 per cent, testifying to a more stable and egalitarian distribution of income.
\end{abstract}

Keywords: income distribution, labor income, Latin America, $19^{\text {th }}$ century, $20^{\text {th }}$ century, Argentina, Brazil, Mexico

JEL Code: E64, N16, N36

* Received 21 December 2009. Accepted 4 May 2010. The author thank Jan Pieter Smits, Bart van Ark, Jan Luiten van Zanden, the participants of the scientific meeting «A Comparative Approach to Inequality and Development: Latin America and Europe», May 8-9, 2009, Madrid and an anonymous referee for their valuable comments on previous versions of this paper. Special thanks to Renato Colistete for providing me with data on Brazilian manufacturing wages. Financial support from the Dutch Science Foundation (NWO) and the European Science Foundation (Global Euronet) is gratefully acknowledged.

a Department of Humanities, Drift 10, 3512 BS, Utrecht, The Netherlands. e.frankema@uu.nl. 


\section{RESUMEN}

La cuota del ingreso del trabajo en la renta nacional es un buen indicador sobre el grado en el que las clases trabajadoras han sido capaces de beneficiarse de los frutos del creciminto económico o, al contrario, sufrir la carga del estancamiento. Este artículo tiene como objetivo reconstruir la cuota del ingreso del trabajo en Argentina, Brasil y México en un contexto de tres sectores, incluyendo el rural, el formal urbano y el informal urbano. Se aprecia que en los tres países la cuota del ingreso del trabajo llega a su máximo hacia mitad del siglo XX. Las fluctuaciones de este ingreso en el caso de Brasil y México fueron muy amplias, con un declive muy agudo en el periodo posterior a 1961 y 1971 respectivamente. En Argentina estas cuotas del ingreso del trabajo tendieron a ser más constantes y mantuvieron niveles cercanos al 50 por ciento, demostrando una distribución de la renta más estable e igualitaria.

Palabras clave: distribución de la renta, renta del trabajo, Latinoamérica, siglo XIX, siglo XX, Argentina, Brasil, México

\section{INTRODUCTION}

Comparative historical studies of income and asset distribution in Latin America have advanced rapidly in recent years. We can roughly distinguish two approaches that have been pursued to improve our insight beyond the post-1970 series of Gini coefficients available for a substantial number of Latin American countries (LACs; Morley 2001). First, new estimates of personal income distribution have been constructed for several benchmark years in the early $20^{\text {th }}$, late $19^{\text {th }}$ and even the late $18^{\text {th }}$ centuries, based on census data or social tables (Bértola et al. 2008; Milanovic et al. 2008). Second, time series have been constructed on the basis of serial data of wages, land rental prices or GDP estimates to disclose major trends in factor income distribution (Williamson 1999; Bértola 2005; Prados de la Escosura 2005; Frankema 2009b, Ch. 7, pp. 177-204). For some LACs, wage-rental series now extend far back into the $19^{\text {th }}$ century (Arroyo Abad 2008). Comparative time series of numeracy, literacy, grade enrollment ratios and land distribution have recently shed more light on the comparative evolution of asset distribution in Latin America (Mariscal and Sokoloff 2000; Baten and Manzel 2009; Frankema 2009a).

This paper aims to contribute to the time-series approach by reconstructing labor income shares in Argentina, Brazil and Mexico in the $20^{\text {th }}$ century. As labor income tends to be more equally distributed than capital 
income, changes in the labor income share are regarded as an important proxy for changes in the secular income inequality trend (Soltow and van Zanden 1998; Lindert 2000; Morrisson 2000). Until 1914, or perhaps even until 1929, we may safely assume that wage-rental series capture a substantial part of interpersonal distributive developments in Latin American economies. Economic growth in the $19^{\text {th }}$ century depended heavily on the development of the agricultural export sector in all three economies, land and low-skilled labor being the key production factors. In the course of the $20^{\text {th }}$ century, however, the urbanization and industrialization process brought about such fundamental changes and increasing complexity in the national production structures that a different accounting framework is required to trace long-run trends in factor income distribution.

Economic modernization not only entailed a shift from agrarian activities located in rural areas toward industrial and service activities located, predominantly, in urban areas. In virtually all LACs it was also accompanied by an increasing polarization of urban income and productivity levels. Hence, with the shrinking of the relative size of the rural economy, the income gaps between the rural and urban sectors were largely replaced by income gaps within the urban sector, and particularly between the formal and informal sectors of the urban economy. The poor living conditions in the present-day shanty towns of large Latin American cities clearly testify to the unchecked growth of the urban sector.

The development literature considers such structural changes as a prerequisite for sustained economic growth: as rural laborers with low levels of productivity become engaged in urban sectors with higher productivity levels, output and incomes will rise accordingly. In Arthur Lewis's (1954) dual-economy framework, the extent of output and income growth depends crucially on the expansion of high value-added jobs in the urban formal sector on the one hand (which in turn depends on investment and capital accumulation) and labor supply growth on the other. If there is a labor surplus, part of the urban labor force will remain un- or under-employed and urban unskilled wages will stick to subsistence levels. Simon (Kuznets 1955, 1966) considered the predicted persistence of subsistence wages as one of the key forces driving increasing urban income inequality during the early stages of modern economic growth.

When considering Latin American economies the question is not whether a dual urban economy perspective is useful or not. Informal sector activities became an indispensable part of economic development during the second half of the $20^{\text {th }}$ century (Cardoso and Helwege 1992, pp. 231-236). Despite unprecedented rates of growth and improvements in average living standards, nearly 130 million people (ca. 25 per cent of the total Latin American population) were still living below the poverty line at the close of the $20^{\text {th }}$ century, of which nearly 52 million had to survive on less than $\$ 1$ a day (World Development Indicators World Bank 2008; see also Astorga et al. 2005). 
At present, the vast majority of these people are living in urban areas and they are mainly occupied in semi-formal or informal economic activities (De Ferranti et al. 2004; World Development Report World Bank 2006). The key question concerns, rather, the degree to which the polarization of urban income and productivity had an impact on the distribution of income. How many rural migrants ended up in informal sector activities characterized by insecure, unstable and ill-defined employment relations? How many people in the expanding urban labor force were able to find employment in the formal sector, with decent pay schemes and social security packages? Did the balance in favor of urban formal sector growth start to lean toward informal sector expansion at some point during the $20^{\text {th }}$ century?

This paper sets out to estimate the effects of changes in the wage and employment structure on the aggregate labor share in national income, taking the development of the urban informal sector explicitly into account. The choice of Argentina, Brazil and Mexico is motivated by the fact that these countries represent the three largest economies in the region and the quality, availability and consistency of the required wage and labor force data are relatively good. Besides, Argentina has witnessed a rather distinct path of economic development in the $20^{\text {th }}$ century compared with Brazil and Mexico, which is also revealed by long-term distributional development.

We find that labor income shares in the mid- $20^{\text {th }}$ century were considerably higher in all three countries than around 1920 and also considerably higher than around 2000 in Brazil and Mexico, but not in Argentina. Labor income shares reached a peak in the early 1950s in Argentina, the early 1960s in Brazil and the mid-1970s in Mexico. The subsequent decline in Brazil and Mexico was primarily due to the relative drop in urban wage levels, rather than the expansion of informal sector employment, although the latter factor must have strongly influenced the former. Section 2 introduces the formal procedure used to decompose national income into underlying factor income shares. Section 3 discusses the trends and features of the labor force data and section 4 discusses the trends and features of the wage data. The labor income share estimates are presented and discussed in sections 5-7 followed by concluding remarks in section 8 .

\section{DECOMPOSING NATIONAL INCOME INTO FACTOR AND SECTOR SHARES}

The empirical analysis presented below builds upon the seminal work of Jeffrey Williamson (1998, 1999, 2002) and Bértola and Williamson (2006). Constructing time series of the ratio of unskilled urban wages to GDP per capita for Argentina, Brazil, Colombia, Mexico, Cuba and Uruguay between 1870 and 1940, Williamson showed that a structural break in the secular inequality trend occurred in the years 1914-1920. Latin American wage 
earners benefited less from the factor price equalization in the Atlantic economy than capital and landowners between 1870 and 1920, but during the 1920s this trend was reversed in all six LACs, except for Brazil. The trend in relative wages suggests increasing income inequality up to 1920 and decreasing inequality thereafter.

By including wage and labor force series for various categories of labor income earners the scope of Williamson's wage-GDP per capita series can be expanded. The wage series in this paper are presented as a percentage share of average GDP per person engaged. The advantage of this approach is that it establishes a direct connection between long-run wage and productivity trends and rules out the potential effects of demographic change on the denominator. For the aggregate labor income share the following estimation procedure is adopted. First, for any given year $(t)$ national income is decomposed into a labor income and a capital income component,

$$
Y=Y_{L}+Y_{C}
$$

where $Y$ denotes total national income and $Y_{L}$ and $Y_{C}$ the respective labor and capital income shares. It follows that,

$$
Y_{L}=Y-Y_{C}
$$

The national labor force can be sectorally decomposed into

$$
E=E_{r}+E_{u f}+E_{u i f}
$$

where $E_{r}, E_{u f}$ and $E_{\text {uif }}$ denote, respectively, the rural, the urban formal sector and the urban informal sector labor forces. Hence, sectoral labor force shares can be written as

$$
E_{r} / E=e_{r}, E_{u f} / E=e_{u f} \text { and } E_{\text {uif }} / E=e_{\text {uif }}
$$

and average labor income per person engaged can be specified as

$$
Y_{L} / E=y_{L}
$$

These components are included in the labor income equation,

$$
Y_{L}=\left(e_{r} \times y_{L, r}\right)+\left(e_{u f} \times y_{L, u f}\right)+\left(e_{u i f} \times y_{L, u i f}\right)
$$

where the first part of the right-hand side denotes the rural sector labor income share, the second part denotes the urban formal sector share and the third part denotes the urban informal sector share. This is the equation that will be estimated in section 5. A complete source description of the data is presented in Table A1. The major limitation of this framework is that the capital income component remains exogenous. This is not because a decomposition of capital income is deemed irrelevant, but simply because 
TABLE 1

DEMOGRAPHIC GROWTH IN $20^{\mathrm{TH}}$ CENTURY LATIN AMERICA

\begin{tabular}{|l|c|c|c|}
\hline & $\begin{array}{c}\text { Peak years of } \\
\text { population } \\
\text { growth }\end{array}$ & $\begin{array}{c}\text { Average annual \% growth } \\
\text { of population (1950-1973) }\end{array}$ & $\begin{array}{c}\text { Average annual \% growth } \\
\text { of population (in peak } \\
\text { years) }\end{array}$ \\
\hline Argentina & pre-1914 & 1.7 & 3.6 \\
Brazil & $1954-1966$ & 2.9 & 3.0 \\
Mexico & $1959-1961$ & 3.1 & 3.3 \\
\hline Latin & $1959-1960$ & 2.7 & 2.9 \\
America & & & \\
(total 47) & & & \\
\hline
\end{tabular}

Sources: UN World Population Prospects: the 2008 revised population database, available at http:// esa.un.org/unpp/. For Argentina pre-1914, see Maddison (2003, pp. 121-127).

we lack the proper data to carry out such a decomposition. In the conclusion we will briefly discuss the implications of this omission for the interpretation of the revealed distributive trends.

\section{POPULATION GROWTH, RURAL-URBAN MIGRATION AND INFORMAL SECTOR EXPANSION}

With the exception of Argentina and Uruguay, the major immigrant countries of the pre-1914 era, all LACs witnessed increasing rates of demographic growth during the first half of the $20^{\text {th }}$ century, culminating in peak rates during the early post-war era (1955-1965). Table 1 shows the rates of population growth in Argentina, Brazil and Mexico as well as the populationweighted regional aggregate peak (based on all forty-seven LACs). The population growth rates in Brazil and Mexico between 1950 and 1973 rank among the highest ever recorded in human history. The sub-Saharan African composite population growth rate, for instance, peaked at 2.9 per cent in the 1980s, which is comparable to the Latin American figure, but much higher than the peak growth rates recorded in most Asian countries ${ }^{1}$.

The high rates of demographic expansion translated into rapid labor force growth with a time lag of one to two decades. Hence, between 1970 and 1985 the labor force in Brazil increased at an annual average of 4.1 per cent and in Mexico even at 4.6 per cent ${ }^{2}$. The pace of labor force growth outstripped

1 Figures based on the United Nations' World Population Prospects: The 2008 Revised Population Database, UN (2008).

2 Groningen Growth and Development Centre and the Conference Board, Total Economy Database, TCB and GGDC (January 2009b). 
population growth because it was not only driven by changes in fertility and mortality, but also by changes in longevity and rising female participation rates. In the 1950s, female employment numbers grew at an average annual rate of 2.7 per cent, in the 1960 s the growth rate jumped to 3.8 per cent and in the 1970 s even to 4.9 per cent ${ }^{3}$. The rise of female participation rates coincided with a sharp decline in crude birth rates, which marked a fairly sudden turning point in the long-run curve of the demographic transition.

In Brazil and Mexico, demographic growth went hand in hand with massive migration from the countryside to the towns and cities. Around the mid-1970s rural population growth in both countries was virtually zero, while the population in towns and cities grew at rates close to 4 per cent. Such a marked difference in the rates of rural and urban population growth is quite uncommon, even in the $20^{\text {th }}$ century developing world. In the newly industrializing countries such as Malaysia, Indonesia, Thailand and the Philippines, the rural population continued to grow until the close of the $20^{\text {th }}$ century. Although population growth rates in the 1960s in most of these countries were comparable with LACs like Brazil and Mexico, the relative share of the rural population in the total population was higher and declined at a substantially slower pace. Consequently, with comparable per capita GDP levels the share of agriculture in total employment in Thailand was more than twice as large as in Brazil around the year 2000: 44.2 per cent vs. 20.7 per cent ${ }^{4}$. Indeed, the absorptive capacity of the rural sector in South East Asian countries was much higher despite the fact that the per capita available land endowments in Brazil and Mexico were much larger than in the land-scarce economies of South East Asia. The historical distribution of land and land market institutions is undoubtedly an important factor in explaining this paradox (Huber and Safford 1995; de Janvry and Sadoulet 2002; Wegenast 2009; Frankema 2010).

Argentina deviated from the more general Latin American pattern of rural-urban migration in at least two important ways. First, the country had always been more urbanized than its neighbors as Spanish settlement in the colonial era and the great wave of immigration in the $19^{\text {th }}$ century were heavily geared toward the capital city of Buenos Aires. Second, as Table 1 shows, Argentina did not have the excessive rates of population growth in the middle of the $20^{\text {th }}$ century experienced by the vast majority of LACs.

The expansion of the urban informal sector in LACs can only be understood against the background of these specific rates of population growth and rural-urban migration. Unfortunately, precise time-series estimates of urban informal sector size are impossible to obtain. The distinction between

\footnotetext{
3 Figures based on the Economically Active Population estimates of the ILO (1997, vol. 3).

4 The data are from de Vries and Timmer (2007). See also The Conference Board (TCB) and Groningen Growth and Development Centre (GGDC), 10-sector Database, TCB and GGDC (January 2009a).
} 
formal and informal economic activities is notoriously unclear. People may be working part-time in formal and informal jobs or combine informal and formal labor services in a single production unit. Moreover, «informality» is a term that touches upon a multitude of legal features of labor activity, which allows for varying degrees of informality.

Despite all sorts of classification and categorization problems the Fifteenth International Conference of Labour Statisticians (ICLS) adopted a resolution on the definition of informal sector workers, stating that informal sector workers primarily operate as "own account workers» or are occupied in "microenterprises» with a low level of organization, with little division of labor and capital and with informal labor relations, based mostly on kinship, family ties or local social contacts. In line with the ICLS, the International Labour Organisation (ILO) has adopted an operational definition in which urban informal sector employment consists of self-employed and unpaid family workers (excluding administrative, professionals and technicians) and workers in micro-enterprises engaging fewer than five or ten employees operating on a wage or non-wage basis (see ILO 1993, 2006; Hussmanns 2004, pp. 1-2).

Since the 1930s, the ILO has collected data on paid employees (wage earners), unpaid family workers and self-employed (own-account) workers in core economic sectors in the Yearbook of Labour Statistics. By calculating the share of urban self-employed in the total labor force and subtracting the share of administrative, professional and technical workers such as lawyers, notaries or clergyman, the first size estimates of the urban informal sector labor force in LACs from the ILO appeared in the early 1980s (PREALC 1982) .

We adopt the ILO definition of informal sector employment to construct time series of the informal sector's share in the total labor force in Argentina, Brazil and Mexico. Figure 1 illustrates the results for Mexico for the period 1930-2003. It appears that the shares of urban self-employed in Mexico were increasing rapidly in the second half of the $20^{\text {th }}$ century, while they remained relatively constant below 10 per cent in the United States and Canada (as they did in most OECD countries). Especially in the 1960s, the gap started to widen: the Mexican-United States gap increased from 2.5 per cent in 1940 and 4 per cent in 1950 to 10 per cent in 1970 and 17.5 per cent in 2001. These size estimates of the urban informal sector labor force are used to estimate the informal sector labor income share in section 5 .

The trends shown in Figure 1 are corroborated by marked shifts in relative sectoral labor productivity. A large share of workers engaged in low value added informal sector activities are absorbed by service sector industries. A sectoral decomposition of services into (1) trade and commerce, (2) transport and communication, (3) finance and real estate, (4) personal and

${ }^{5}$ Note that people who are officially registered as «unemployed» are not included in the category «self-employed». For comparative purposes this separation is adequate because it distinguishes unemployment from under-employment. 
FIGURE 1

URBAN SELF-EMPLOYED AS PERCENTAGE SHARE OF THE LABOR FORCE IN MEXICO, CANADA AND THE UNITED STATES, 1930-2003

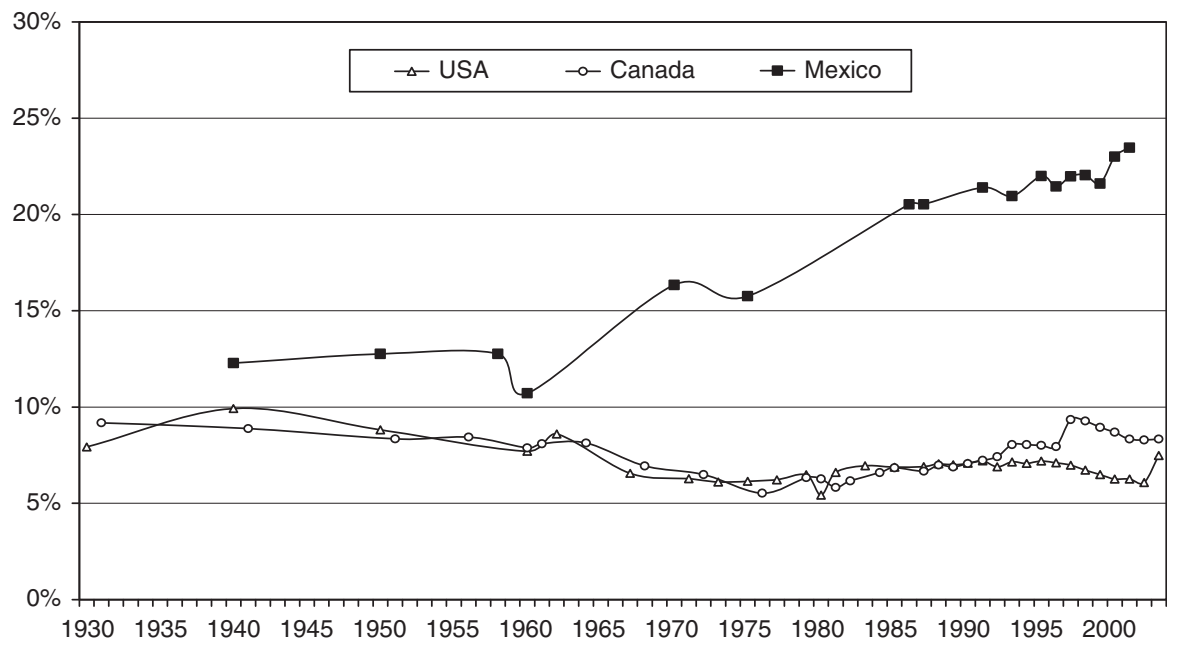

Source: ILO, Yearbook of Labor Statistics, 1936-2005.

social services and (5) government services, points out that low-productive workers were mainly concentrated in trade and commerce activities. Figure A1 presents the comparative labor productivity trends of the trade sectors vs. the other service sectors in Argentina, Brazil, Mexico and the United States in the period 1950-2000.

Although the comparative productivity performance of the U.S. trade sector improved gradually, labor productivity of the trade sector increasingly lagged behind the three LACs. In Brazil, the decline began in 1960. In Mexico, this decline was ushered in by a marked break point around 19751982. In Argentina, the decline was more moderate and was reversed during the 1990s. Mulder's comparative study of service sector productivity in Latin America confirms the decline in the productivity of the trade sector. After a gradual increase, the ratio of relative productivity levels in Brazilian trade vs. the United States dropped sharply, from a peak of 34 per cent in 1975 to 13 per cent in 1995 (the last year of Mulder's analysis). The Mexico-United States ratio dropped after a peak of 25 per cent in 1982 to 12 per cent in 1995 (Mulder 1999, p. 152). According to Mulder, the sharp turn in the mid-1970s (Brazil) and early 1980s (Mexico) was indeed caused by the swelling numbers of petty traders in urban areas. The timing is important because it coincides almost perfectly with the trends observed in the informal sector labor force share. 


\section{LONG-TERM TRENDS IN WAGES AND LABOR PRODUCTIVITY}

As indicated above, the wage data for different categories of wage earners will be taken as a percentage share of average GDP per worker. The time series for Argentina, Brazil and Mexico are graphically presented in Figure 2A, B and C, respectively. Some preliminary remarks regarding the wage series have to be made.

First, the wage series contain gaps that have been filled by linear interpolation. Hence, only the dots in the graphs represent actual observations. Because of these data gaps the series are suitable for analyzing long-term trends, but one should be cautious about drawing inferences from yearto-year fluctuations. The use of interpolation techniques tends to smooth annual fluctuations and during periods of high inflation (and there were several such periods) nominal wages and nominal GDP estimates may diverge or converge rapidly. As nearly all of the wage series are based on daily or monthly wage data, the precise timing of their observation matters, especially in periods when nominal prices change rapidly from month to month, or even from day to day. Such statistical biases tend to fade out in the long run, but may disturb the short-term picture.

FIGURE 2A

ANNUAL WAGES AS PERCENTAGE SHARE OF GDP PER PERSON ENGAGED, ARGENTINA 1870-2000

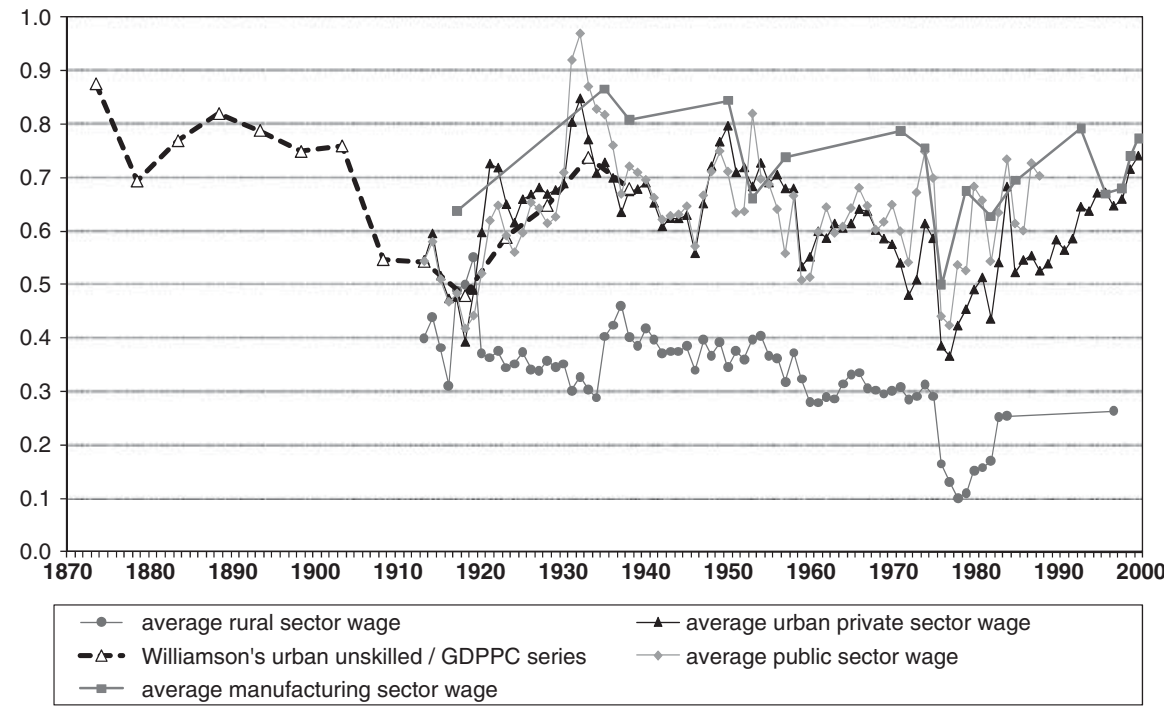

Source: see Table A1. 
FIGURE 2B

ANNUAL WAGES AS PERCENTAGE SHARE OF GDP PER PERSON ENGAGED, BRAZIL 1900-2000

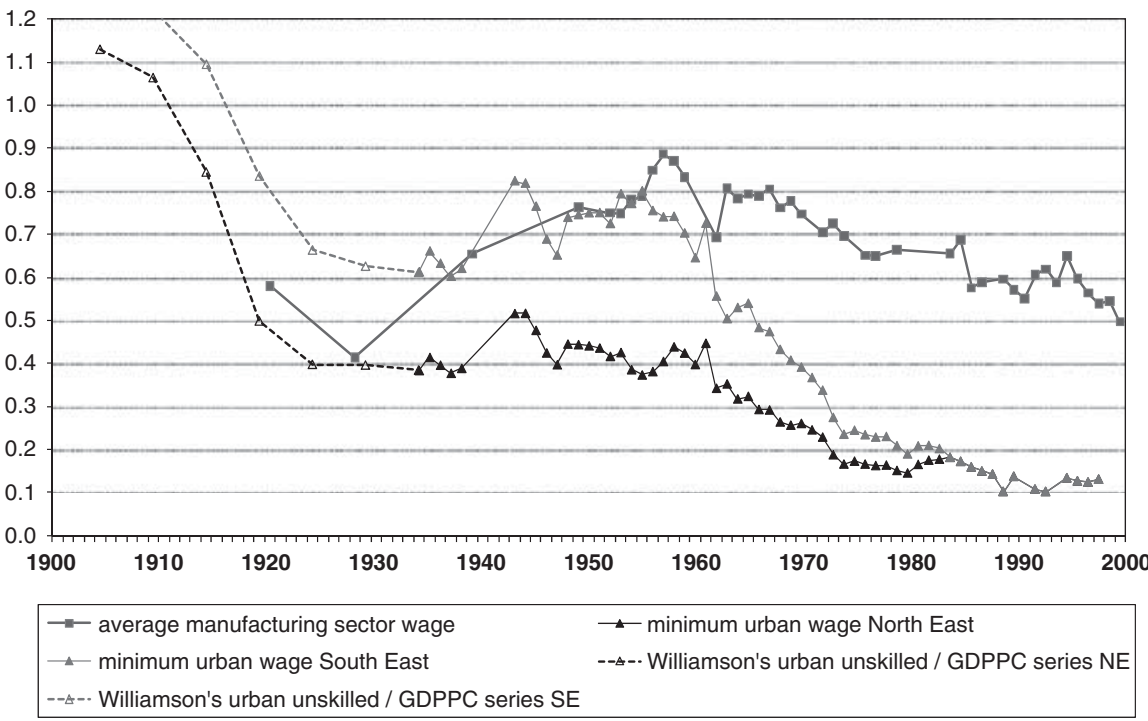

Source: see Table A1.

In constructing the wage series a fixed formula has been applied to convert hourly, daily or monthly wages into annual wages. This formula consisted of the following assumptions: 8 working hours make one working day, 25 working days make 1 month and 12 months make 1 year. Hence, an annual wage consisted of 300 working days of 8 hours, which is 2400 hours a year. Although we know that the number of annual working hours gradually declined through the $20^{\text {th }}$ century, we have hardly any information about the number of working hours for specific categories of wage earners that would cover the entire period 1870-2000. Given these data limitations and our preference for methodological transparency this formula has been applied consistently.

The figures of GDP per worker relate to the entire labor force, including the unemployed. In practice it is not so easy to make a clear distinction between employed and unemployed in the economically active population, since the vast majority of those registered as unemployed are engaged in productive activities of some sort, often in the informal sector. Since the informal sector workers are explicitly taken into account in the analysis of structural change we did not remove unemployed workers from the labor force in order to refine the labor productivity estimates. Finally, it should be 
FIGURE 2C

ANNUAL WAGES AS PERCENTAGE SHARE OF GDP PER PERSON ENGAGED, MEXICO 1880-2000

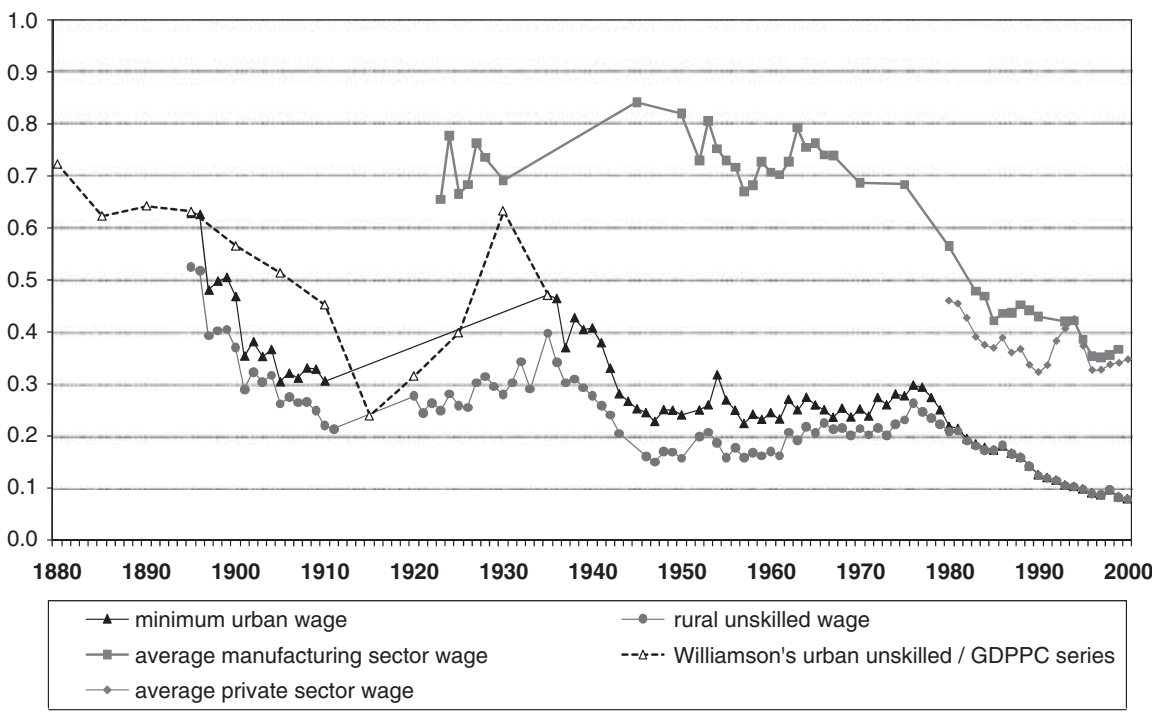

Source: see Table A1.

noted that, because wages are expressed in percentage shares rather than absolute numbers, a growing gap in percentages does not necessarily reflect absolute wage divergence.

\subsection{Argentina, 1870-2000}

Figure 2A contains five wage series: (1) the average rural sector wage 1913-1997, (2) the average urban private sector wage 1913-2000, (3) the average public sector wage 1913-1988, (4) the average manufacturing sector wage and (5) Williamson's urban unskilled/GDP per capita index that is linked to the 1913 level of the urban private sector wage.

The figure shows that for the period 1913-1940 the Williamson series and the urban private sector wage series correspond closely, which confirms the reliability of both series. The urban wage series show a distinct wave-shaped pattern from 1870 onward. The urban wage levels as a percentage share of GDP per worker were relatively high in 1870 (87.5 per cent), reached a low in 1918 (39.3 per cent), increased rapidly in the 1920s and reached a temporary peak in the early 1930s. Until the late 1950s, the wage share retained levels 
around 70 per cent. From the early 1960s until the mid 1970s the wage share declined to around 60 per cent, which was then followed by a steep drop during the early years of the military junta in 1976-1977. This drop occurred in the urban as well as rural wage series. From 1982 onward, urban wages recovered strongly and by the end of the century they were restored to the 1950s levels around 70 per cent of GDP per person engaged.

During the World War I rural and urban wage levels converged, but in the 1920 s and early 1930s they strongly diverged. The resulting rural-urban wage gap has never been closed during the post-war era. Whereas urban wages had a tendency to fluctuate sharply, rural wages remained relatively constant between 1913 and the late-1950s, around 40 per cent of GDP per worker. Manufacturing wages roughly followed the long-run trend in average urban wages; they were slightly higher, but show similar fluctuations, especially in the 1970s. Average wages in the public and private sectors deviated marginally. Only toward the final quarter of the $20^{\text {th }}$ century did public sector wages tend to be a little higher. Altogether, these figures suggest that the period around 1870 and the period between 1930 and 1960 displayed a relatively high share of wage income in total national income. Combining the wage data with the labor force composition data in section 5 supports this view.

\subsection{Brazil, 1900-2000}

Figure 2B contains five wage series: (1) the official urban minimum wage in the north-eastern part of Brazil 1934-1998 (figures refer to Fortaleza, Ceará), (2) the official urban minimum wage in the south-eastern part of Brazil 19341998 (figures refer to Rio de Janeiro), (3) the average manufacturing sector wage 1920-2000 and (4 and 5) Williamson's urban unskilled/GDP per capita index for, respectively, the northeast and southeast. Williamson's index figures are linked to the 1934 levels of both minimum wage series.

Similar to Argentina and Mexico, the wage series follow a wave-shaped pattern, with remarkably high levels around 1900. However, urban unskilled wage shares declined dramatically during the first two decades of the $20^{\text {th }}$ century and remained fairly stable for nearly four decades until the early 1960s. In the southeast, wages were fluctuating around 70 per cent of average GDP per worker. In the northeast, the share fluctuated around 45 per cent. After 1961, both series simultaneously declined and converged. In 1984, minimum wages became equal for the entire country.

The observation that urban unskilled wages were so high at the beginning of the century compared to average GDP per worker poses a challenging puzzle. Have we perhaps underestimated GDP levels or overestimated wage levels? To answer this question further research, which falls beyond the scope of this paper, is required. It should be noted, however, that the recent work of Bértola et al. (2009, p. 15) suggests that Brazilian GDP in the late 
$19^{\text {th }}$ century may have been underestimated by the conventional estimates of Maddison (2003). It should also be noted that in the late $19^{\text {th }}$ century Brazil was still a predominantly rural country, with a relatively small urban wageearning class (see Lewis 1986).

Wages in the manufacturing sector show a rapid increase since 1920. Starting out at levels comparable to the urban minimum wage, the average manufacturing laborer soon became much better off. Especially during the 1950s manufacturing workers were earning much higher wages than their peers in the rural and low-productive urban sectors. Throughout the postwar era the gap remained large, but all wage workers faced declining shares from the 1960s onward. The manufacturing wage share declined from a little over 100 per cent in 1962 to a little under 50 per cent in the year 2000 . Official minimum wages in Rio de Janeiro declined from 72.5 per cent in 1961 to ca. 13 per cent in 1998. It is especially this large drop in minimum wages, which drives the sharp and continuous decline of the labor income share in Brazil since the 1960s shown in section 5.

\subsection{Mexico, $1880-2000$}

Figure 2C contains five wage series: (1) the rural unskilled wage 1895-2000, (2) the urban minimum wage 1895-2000, (3) the average manufacturing sector wage 1930-2000, (4) the average private sector wage 1980-2000 and (5) Williamson's urban unskilled/GDP per capita index that is pared to the 1935 level of the urban minimum wage.

Similar to Argentina and Brazil, the Mexican wage series were characterized by distinct phases of rise and decline. From 1880 until 1915, urban and rural unskilled wage shares declined substantially. This is confirmed by Williamson's series. Between the two world wars urban and rural unskilled wage shares tended to increase from levels close to 20 per cent in 1915 to over 30 per cent in the late 1930s. During the 1940s the rural and urban minimum wage shares decreased, followed by a phase of modest recovery between the early 1950s and mid 1970s. During the last quarter of the $20^{\text {th }}$ century the wage shares declined to unprecedented low levels of around 8 per cent in 2000.

The trend in the wage shares of the manufacturing sector diverged markedly from these two series and closely resembled the patterns found in Argentina and Brazil. Since the mid-1930s, and especially during the 1940s, the gap increased rapidly. Wage differentials between the rural and lowproductive urban sectors and the manufacturing sector in Mexico were significantly larger than in Argentina. During the early post-war era the average manufacturing employee earned at least three times as much as an urban minimum wage earner, and this ratio rose in the late 1980s and 1990s to more than four times as much. Similar to Brazil, but unlike Argentina, rural 
and urban wage earners rapidly lost ground during the last quarter of the $20^{\text {th }}$ century. Considering the entire period the relative share of wages in national income appears never to have been as low as during the 1990s.

On the whole, the wage/GDP per worker series suggest that the gap between urban formal sector wages and the rural or urban minimum wages rose significantly during the $20^{\text {th }}$ century in Mexico and Brazil and to a lesser extent in Argentina. Wage workers in the least productive sectors, earning a minimum or subsistence wage, lost ground to wage workers in the more productive formal sectors of the urban economy. It will be shown in the next section that while in Brazil and Mexico the wage earners in the urban formal sector lost ground compared with capital income earners, in Argentina the total labor income share remained relatively constant. The rapid growth of the rural-urban and within-urban wage gap during the 1930s to 1950s reflects the urban bias, and especially the manufacturing bias, of ISI policies, which were implemented by respective governments to promote industrialization and structural change. These policies resulted in the emergence of an urban middle class of industrial workers, but this group remained relatively small. Facing overwhelming competition on the labor market for well paid jobs, lacking the demanded skills, and lacking proper alternatives, the majority of rural migrants eventually ended up in the lower ranks of the urban income pyramid.

\section{RECONSTRUCTING LABOR INCOME SHARES}

Before discussing and interpreting the trends in the labor income shares that we will present in this section, we need to discuss some assumptions that have been made in our estimation procedure.

First, data gaps were filled by interpolation and extrapolation. For the pre-1940 period sectoral labor force data are based on decennial census estimates, which were interpolated with a nonlinear growth trend, resembling the exponential nature of population growth. Urban informal sector labor force estimates for the pre-1930 period were linearly extrapolated, assuming an initial share of 10 per cent of the labor force in 1913 Argentina, 5 per cent in Mexico in 1900 and 5 per cent in Brazil in 1920. The larger share in Argentina accounts for the comparatively high rate of urbanization of this country in the early $20^{\text {th }}$ century. Since the labor force estimates for Brazil in the pre-1920 period are very weak, the estimation of the model has been limited to the period 1920-2000. Brazilian labor force estimates for 19201940 were obtained by assuming a constant labor participation rate of 30 per cent of the total population.

Second, own account workers do not earn wage income. In national income accounting practices the earnings of family farms or owner-operated micro-enterprises are registered under the heading «operating surplus». It is 
virtually impossible to disentangle the returns to labor and capital in owneroperated production processes precisely. To circumvent this problem, all own account workers were assigned a shadow wage, which was set equal to the urban minimum wage. In the case of Argentina, the wages of informal sector workers were set equal to the average rural wage. The figures for Mexico indicate that the gap between urban minimum wages and rural unskilled wages were small. For Brazil, rural wages are represented by the minimum wage levels in the northeast and urban informal sector wages are represented by the geometric average of the urban minimum wage in Rio de Janeiro (southeast) and Fortaleza (northeast). In Mexico and Brazil, the average manufacturing sector wage represents the average urban formal sector wage. Manufacturing wages and average urban private sector wages appear to move closely together in Argentina (see Figure 2A), and the average private sector wages in Mexico for the period 1980-2000 also suggest that the manufacturing wage level serves as a good proxy of average labor remunerations in the urban formal sector (see Figure 2C). There may, however, be a problem with the representativeness of the Brazilian manufacturing wage series. We will discuss this further below.

Third, there is a notable difference in the level of precision of the labor force data on the one hand, and the GDP and wage data on the other. Labor force series have been constructed on the basis of interpolated benchmark observations, while the annual series of wages and GDP tend to reflect shortterm fluctuations much better. A related problem, which has been briefly addressed above, is that differences in the adjustment of nominal wages and GDP figures in response to inflation may disturb labor income estimates in the short run. Hence, the estimates presented below should be primarily used to analyze the long-term secular trend. Therefore, a five-year moving average is added to the graphs presented in Figure 3A, B and C.

\section{DO THE RESULTS MAKE SENSE?}

The average labor income share of Argentina was 49.5 per cent, but the levels varied between 29 and 62 per cent. Mexico's average was 34.5 per cent varying between 21 and 48 per cent and Brazil's average was 45.9 per cent, varying from 32 to 60 per cent. Indeed, we find considerable fluctuations in the secular trend of factor income distribution in all three LACs during the $20^{\text {th }}$ century. Do these results make any sense? This section provides a brief explanation of the most remarkable developments, starting with a comparison of our Argentinean series with some alternative (though much shorter) labor income series.

Galiani and Gerchunoff (2003) discuss several post-war series of the Argentinean labor income share from various sources (see Figure 3A), showing peaks in the early 1950 s varying between 45 and 55 per cent, 
FIGURE 3A

LABOR INCOME SHARES IN NATIONAL INCOME, ARGENTINA 1913-2000

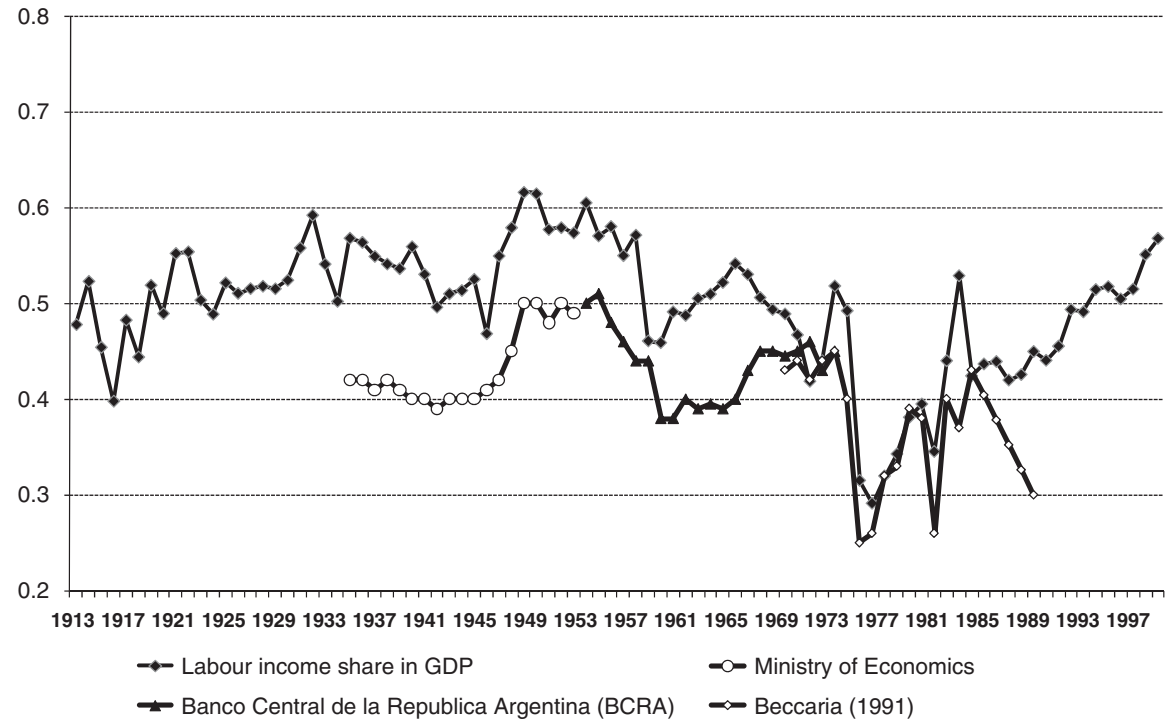

Sources: see Table A1. The additional series were taken from Galiani and Gerchunoff (2003, p.152), but are originally from the Ministry of Economics, the Argentine Central Bank and a study by Beccaria (1991).

(pp. 151-153). These levels are a bit lower than our estimates, but the longterm trend appears to be almost identical, except for the past 5 years of Beccaria's estimates, for which we do not really have a good explanation. One of the more likely reasons for the difference in levels is the explicit inclusion of informal sector labor incomes in our series. As (part of) these incomes were not taken into consideration in the national income accounts, our series may overstate the labor income share. On the other hand, leaving them out leads to an underestimation of the labor income share. In other words, whereas our series may be considered as an upper boundary, the benchmark series may in fact reflect a lower boundary.

In Argentina, the dramatic collapse of the labor income share in the mid1970s appears in both series. The collapse of the labor income share in 1976 was the result of the attempt of the Videla regime to curb mounting inflation after its military coup in March of that year. The newly appointed Minister of Economy, Martínez de Hoz, decreed an immediate freeze on wages (Lewis 1990, pp. 460-469). Inflation fell temporarily, but this could not prevent a dramatic fall in the purchasing power of most wage earners. When inflation span out of control again in 1977, wages became subject to a series of ad hoc adjustments and wage freezes. Recurrent cycles of inflation, untimely wage 
FIGURE 3B

LABOR INCOME SHARES IN NATIONAL INCOME, BRAZIL 1920-2000

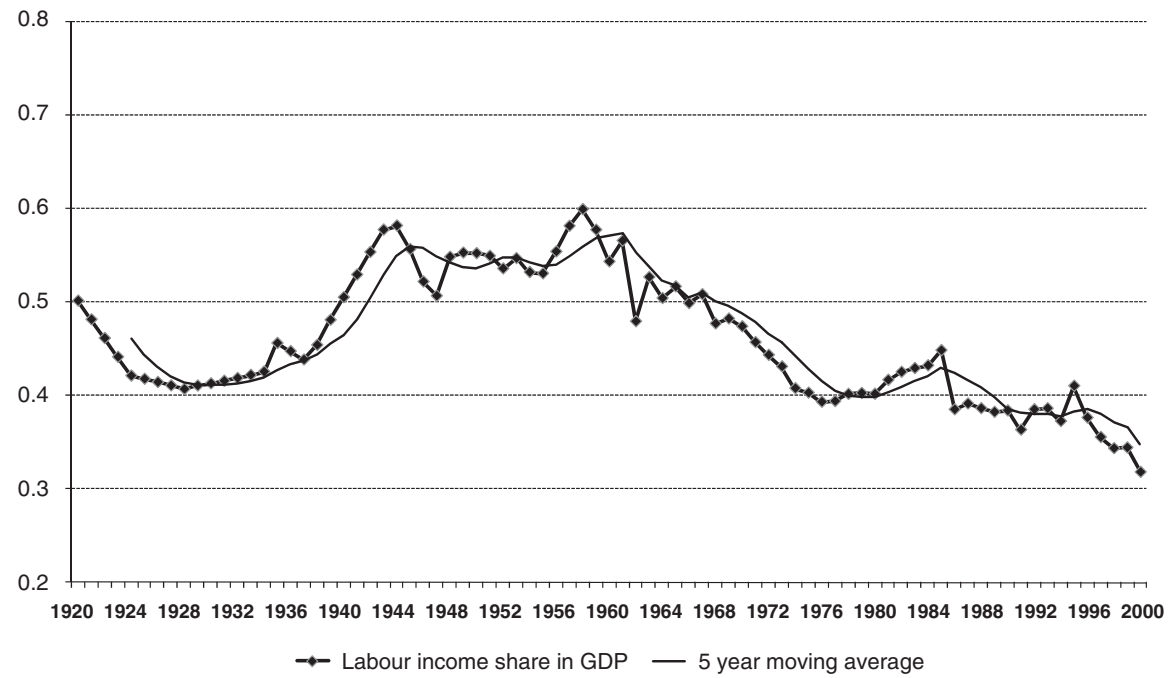

Source: see Table A1.

adjustments and an array of economic reform schemes (privatization of state enterprises, mass lay offs, reduction of trade barriers, introduction of new currencies) made the income position of wage earners extremely insecure during the late 1970s and early 1980s (Lewis 1990).

There are also some notable similarities in the pre-1940 trend in Argentina, Brazil and Mexico. The gradual rise of the labor income share during the inter-war years occurred in all three countries. As pointed out by Williamson in a number of studies, the relative value of wages declined rapidly before 1914 and recovered during the inter-war years (O'Rourke and Williamson 1999; Williamson 1999, 2002). In Mexico and Argentina, this recovery started in the 1920s, in Brazil it started one decade later, during the 1930s. This tendency is almost perfectly corroborated by the labor income share estimates presented in Figure 3. (O'Rourke and Williamson (1999) explain the trend reversal around the World War 1 as the result of a process of Atlantic factor price equalization driven by pre-1914 Atlantic market integration, followed by a period of de-globalization during the inter-war years (pp. 74-75). However, for Argentina and Mexico, the timing of the reversal does not seem to coincide with the predictions of the globalization hypothesis. The big collapse in Latin American exports only occurred in the wake of the 1929 crisis, especially in Argentina. Argentinean exports suffered from the Great Depression in the 1930s, but in the 1920s Argentina managed 
FIGURE 3C

LABOR INCOME SHARES IN NATIONAL INCOME, MEXICO 1900-2000

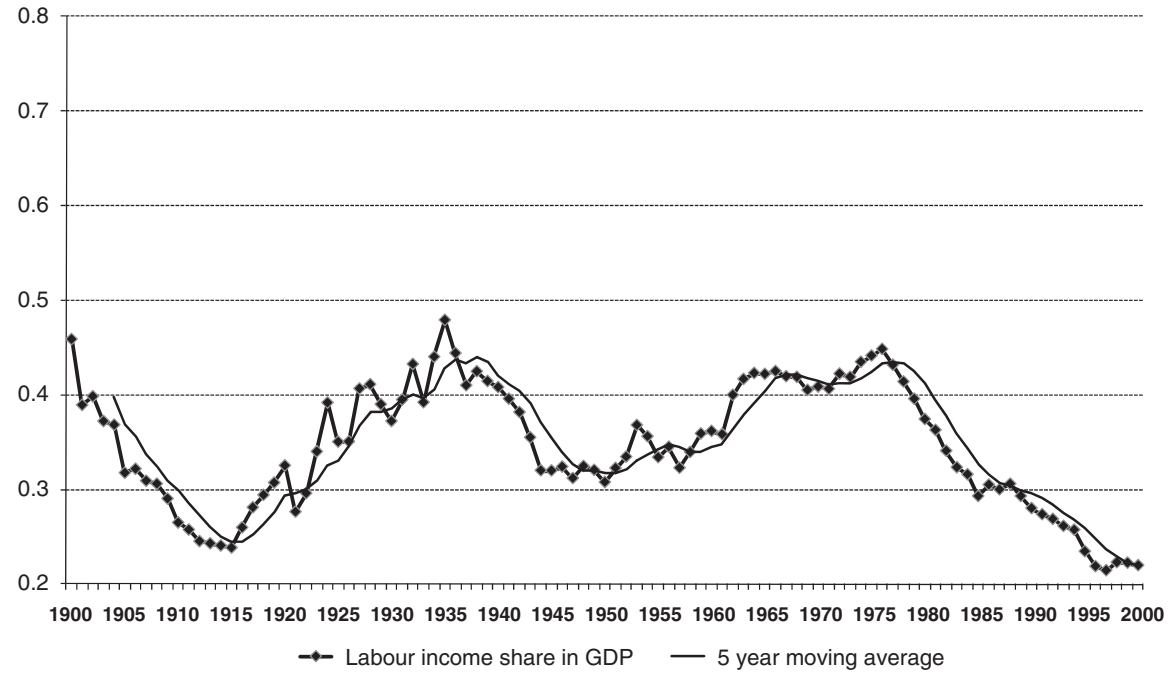

Source: see Table A1.

to expand its export sector in comparison with the years before 1913 (BulmerThomas 2003, pp. 163-164). Hence, a trend break in the early 1920s is difficult to reconcile with the perceived impact of changing relative factor returns.

Government policy responses to the increasing political presence of trade unions may be an important additional factor to explain the marked increase in the wage-GDP ratio (Galiani and Gerchunoff 2003, p. 131). In this respect, it is interesting to observe that the labor income share in Brazil declined until the mid-1930s. This could signal the relatively weak position of the labor movement in the country and the relatively strong position of the land-based elite. In Argentina and in Mexico (especially after the Mexican revolution) the social and political pressure to improve social policies was greater than in Brazil (Levine 1999, pp. 94-96; Frankema 2009b, Ch. 7, pp. 177-204). However, the question regarding the extent to which deliberate wage policies were responsible for the reversal of the labor income share warrants further research.

There was a temporary, but rather sharp fall in labor income shares in Mexico during the 1940s, which did not take place in Argentina and Brazil. As early as the 1950s several scholars drew attention to the rapidly worsening of Mexican income distribution during the 1940s. They argued that entrepreneurial incomes had risen rapidly while nominal wages and salaries were rising slowly and real wage rates were even declining (Rosado and Noyola 
1951; Sturmthal 1955; Navarette 1960). Hanson (1971) explains this sudden interruption of the long-run pattern of increasing wage shares as a result of the special geopolitical position of the Mexican economy during the World War II. Before the war, Mexican industry had operated below capacity, but because of rapidly increasing U.S. demand in the 1940s, capital resources became fully employed. Meanwhile, heightened inflation eroded nominal wage gains, especially the formal minimum wages. It has been estimated that industrial output for foreign markets rose by 600 percent between 1939 and 1943. Increasing job opportunities in the cities intensified structural change, but the collectively negotiated wage agreements (which were made every other year) were insufficient to keep pace with rising price levels driven by the excess demand of the U.S. war economy. Consequently, real wages in some sectors were to fall by as much as 30 per cent (Hanson 1971, pp. 71-72). In other words, the deviation of the Mexican labor income trend is probably caused by rather specific circumstances, rather than by structural differences.

Compared with Mexico and Argentina the labor income shares in Brazil during the mid- $20^{\text {th }}$ century appear surprisingly high. These high levels were caused by two factors. First, minimum wage levels in urban areas were comparatively high and, second, the Brazilian manufacturing wage series were much higher compared with average labor productivity levels, than in either Argentina or Mexico (see Figure 2). The scarce evidence of Gini coefficients of income distribution suggests that inequality was indeed lower in the 1950s and 1960s than in later decades in Brazil (see Frankema 2009b, Table 1.1, p. 3). The problem, however, is that we cannot reconcile these levels in comparison with Argentina, whose income inequality figures were, if anything, lower throughout the $20^{\text {th }}$ century, not higher. It is certainly possible that Brazilian manufacturing wages in the ISI period overstate average urban formal sector wages and, hence, inflate the estimated labor income share in the 1950s. This signals the sensitivity of our approach to the representativeness of the wage series. Yet, even if we were to make a downward adjustment of, say, ten percentage points, the long-term picture would not change dramatically: the upswing in the mid-1930s and the decline in the post-1961 period would be less profound but still visible.

\section{FALLING LABOR INCOME SHARES IN BRAZIL AND MEXICO}

The crucial question that remains unanswered, however, concerns the explanation of the prolonged decline in labor income shares in Brazil and Mexico during the second half of the $20^{\text {th }}$ century and the absence of such a prolonged decline in Argentina. We will provide a tentative explanation by placing the differences in population growth and rural-urban migration as discussed in section 3 at the center of our exposition. 
First, we should note that the rise of the wage-earning classes on the national income ladder took place during the heyday of ISI policies in all three countries. These policies were characterized by increasing state intervention in the labor market and it is during this period that labor unions were able to cash in on their increased bargaining power, especially when populist governments tried to broaden their support among the urban working classes, for instance, under Péron in Argentina or Vargas in Brazil. ISI policies offered a rate of protection to new and vested industries, which allowed a larger amount of flexibility in wage setting than under competitive market circumstances. Due to the reduction of international competition and the support of state subsidies, wages could be raised above market levels, at least temporarily. Yet, insofar as these wage increases were not completely backed up by productivity increases, they had to be unsustainable in the long run (see Edwards 1995; Cortés Conde 2006).

Our hypothesis is that as long as the inflow of new job seekers in the urban labor force remained fairly limited, urban economic growth, under the flag of import substitution industrialization investments, was compatible with cohesive income policies. However, when urban labor force growth accelerated, the vested interests of the unionized part of the work force were increasingly difficult to square with the growing number of outsiders (see Cardoso and Helwege 1992, pp. 231-236; Thorp 1998, pp. 172-178). This undermined the internal stability of labor unions and focused much of the political attention on the trade-off between formal wage levels (and related high costs of labor) and employment creation. The structural imbalances in the urban labor markets continued to exist for a while, but would at some point have to be reversed and result in a prolonged decline of urban wage levels.

The data allow us to investigate the extent to which declining labor income shares in Brazil (after 1961) and Mexico (after 1976) were caused by expanding informal sector employment $\left(e_{u i f}\right)$, decreasing urban minimum wages $\left(y_{L, u i f}\right)$ or decreasing wages in the urban formal sector $\left(y_{L, u f}\right)$. By fixing each of these three factors separately in the equation at the level of 1961 (Brazil) and 1976 (Mexico), we can simulate the long-term trends. Figure 4A and $\mathrm{B}$, show the results.

The simulations show that in Brazil, as well as in Mexico, the relative decline of urban formal sector wages was the most important proximate cause of the declining aggregate labor income share. Fixing the urban formal sector wage levels at their 1961 level in Brazil removes almost the entire observed decline of the labor income share. In Mexico keeping formal urban sector wages constant at the 1976 level would not prevent the decline of the labor income share entirely, but it would reduce the decline from a mere 23 to 9 per cent. Surprisingly, the expansion of informal sector employment from ca. 14 to 25 per cent of total employment in Brazil (1961-2000) and ca. 16 to 23 per cent in Mexico (1976-2000) does not seem to have a large impact. This is, of course, an interesting finding in itself, but it would be wrong to infer from this that the informal sector was a completely unimportant factor. 
FIGURE 4A

SIMULATED LABOR INCOME SHARE PATTERNS, BRAZIL 1961-2000

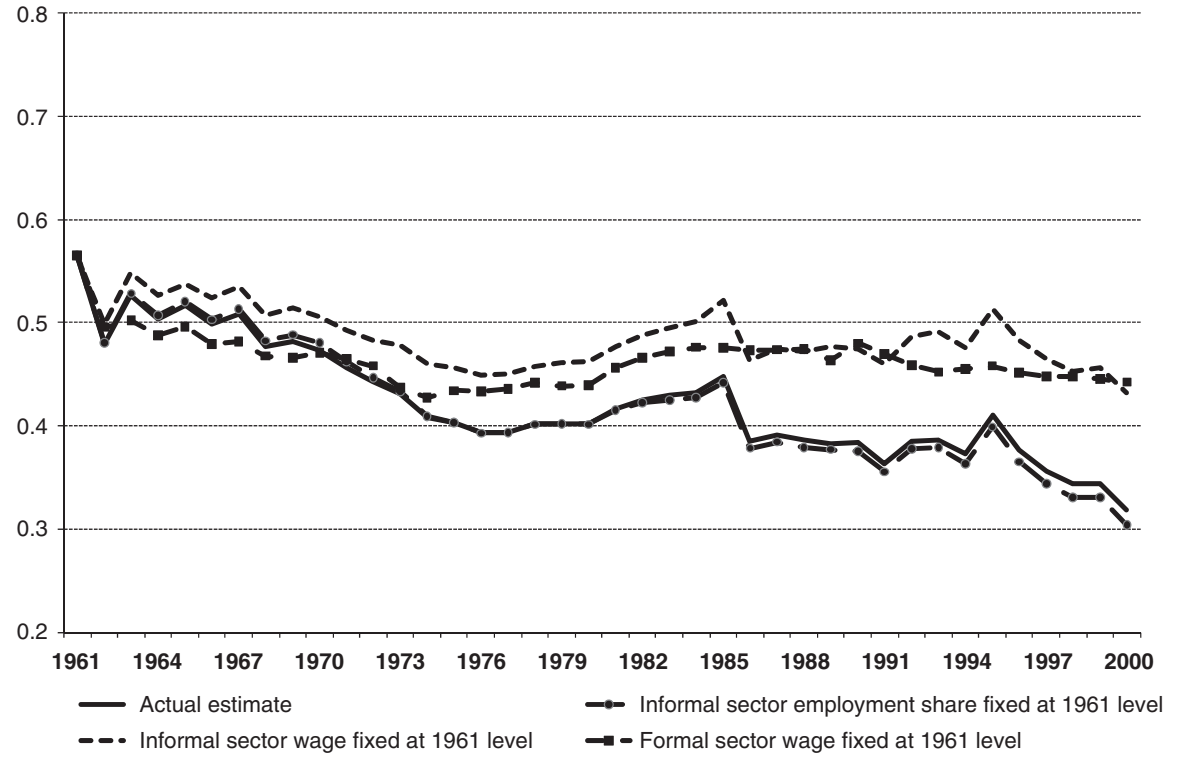

Source: see Table A1.

The growing shares of informal sector activities in the urban sectors of Brazil and Mexico reflected a powerful underlying force: high formal sector wage costs limited the opportunities of employment creation and pushed people into informal sector activities. The growing numbers of petty traders in the cities, however, built up the pressure on the existing income gaps. Typically, in situations with mounting conflicts of interest reforms are often carried through in times of a major economic crisis or a major political regime change, situations that pave the way for reforms. Is there any evidence for such a break point in Brazil and Mexico? We believe there is.

The post-1961 decline in Brazil was induced by a number of economic and political developments related to the macro-economic imbalances inherent in the ISI policies of the populist governments of, among others, Vargas and Kubitschek after the 1930s. In 1961 the Kubitschek government fell in the midst of a severe economic recession and surging inflation. The government of Goulart that followed, was unable to re-establish macroeconomic order, and was ousted by the military dictatorship imposed in the spring of 1964. Authoritarian rule lasted until 1985 (Levine 1999, pp. 121-128). The political stirrings were fueled by differences in opinion on how 
FIGURE 4B

SIMULATED LABOR INCOME SHARE PATTERNS, MEXICO 1976-2000

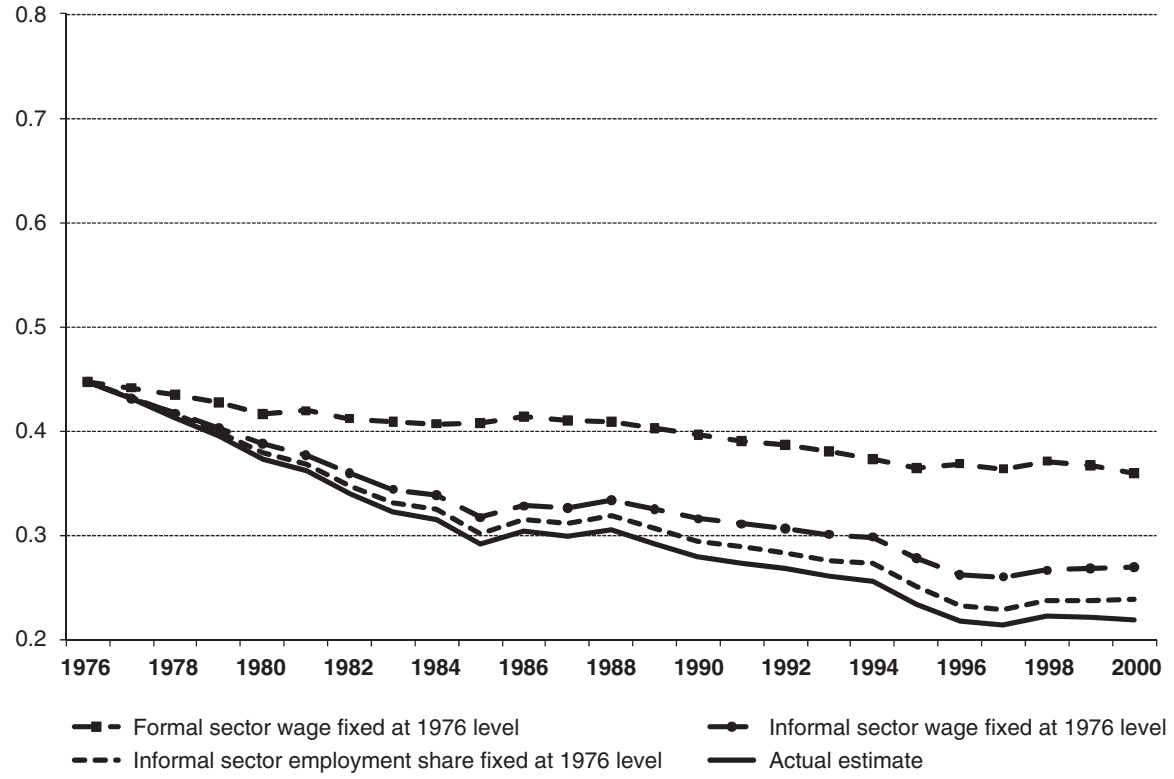

Source: see Table A1.

to stop a further deterioration of the economic situation, and, in particular, how to tackle the rapidly increasing rates of inflation.

Goulart's policies aimed to keep workers' wages on a par with the rising costs of living, by enforcing a vast number of price controls and allowing wages to adjust. These measures increased inflation and encouraged black market trade. Shortly after the military coup the controlled prices were readjusted upward while wages were frozen in combination with restrictive fiscal and monetary policies. It took the authoritarian regime three years to re-establish macro-economic stability, after which a new phase of strong growth (1968-1973) set in. The return to economic stability had come along with a notable increase of income inequality, however: the stabilization policies resulted in a year-after-year decline of real minimum wages during the second half of the 1960s (see also Figure 2B) and the introduction of tax reforms in favor of the high-income classes also contributed to a rise in inequality (Baer 1984, pp. 58-61).

A comparison with the post-1976 years in Mexico yields some important similarities. Mexican economic policy reforms were introduced in response to uncontrolled inflation and soaring public debt in the midst of a severe 
economic crisis. The reforms were implemented after a change of political leadership between Echeverría and López Portillo. Portillo succeeded, at least for some time, in bringing down inflation and restoring investors' confidence, but the bill for the restoration of macro-economic stability was paid by the working classes. The purchasing power of wage workers declined as wages did not keep pace with inflation and unemployment soared (Gereffi and Evans 1995, pp. 215, 223-225). A series of new oil discoveries helped Portillo to service the debt with new foreign loans and, in the meantime, set up major investment programs increasing public spending by ca. 17 per cent a year between 1978 and 1981 (Levy et al. 2006, p. 161). These projects created many new jobs in the government sector, but also pushed the escalating foreign debt to unmanageable proportions, bringing Mexico to the brink of economic collapse in 1982 after world oil prices fell.

In both countries, the policy reforms implemented in a context of severe macro-economic instability set off a long-term decline in the labor income share, which started before the period of real trade liberalization in the 1980s. As Figure 4 shows, the decline in the labor income share was primarily due to a continuous deterioration of wages in the urban formal sector. Wages did not decline in nominal terms, but they were often insufficiently adjusted to rising inflation rates. In Brazil, the military dictatorship guaranteed the maintenance of more conservative fiscal and monetary policies and restricted the working-class agenda. In Mexico the crises of 1976 and 1982 paved the way for a more fundamental change in economic policy, partly instigated by the demands of the International Monetary Fund in return for the necessary loans.

During the liberalization program of the 1980s, state enterprises were privatized, trade tariffs were reduced and wages were increasingly determined by standards of international competitiveness. This prevented wages from rising again, but also induced greater inequality in average wages among various industries (Frankema 2009b, pp. 194-197). Hence, when the limitations of the ISI-led growth strategy really surfaced in the wake of renewed international competition, the working classes in Brazil and Mexico had already been forced to adapt to the new political and economic realities, which prioritized business profits over wages, public revenue over expenditure and, more generally, prioritized the interests of the higher income classes over those of ordinary wage workers.

The question why the obvious break point in Argentina in 1975 did not result in a prolonged decline as it did in Brazil and Mexico can now also be answered. The crucial difference was that Argentina did not witness a radical demographic transition in the second half of the $20^{\text {th }}$ century. On the contrary, population growth was moderate and rural-urban migration rates were also quite low. In Argentina, a return to pre-crisis labor income shares in the 1980s was possible because the pressure of new generations of job seekers on the labor market was considerably lower. Unlike the situation in 
Brazil and Mexico rural wages in Argentina started to rise again after the late 1970s, ending a long period of decline, but helping to retain within-country wage gaps at moderate levels. This helps to clarify why Argentina was able to maintain considerably lower levels of income inequality in the second half of the $20^{\text {th }}$ century, with Ginis ranging between 0.43 and 0.49 , whereas the Ginis in Mexico and Brazil rose to seemingly unprecedented levels of ca. 0.59 and 0.61 , respectively ${ }^{6}$.

\section{CONCLUSION}

This paper has made an attempt to reconstruct labor income shares in Argentina, Brazil and Mexico during the period 1870-2000 on the basis of a three-sector framework. The labor income share series were subsequently used to analyze the potential effects of structural change and, in particular, the expansion of employment in the informal sector. We found some notable differences and similarities in the movement of factor income shares in such economically variegated LACs as Argentina, Brazil and Mexico. A sharp decline of the labor income share during the late $19^{\text {th }}$ and early $20^{\text {th }}$ centuries occurred in all three countries, but the timing of its reversal differed. In Argentina and Mexico, the trend break occurred immediately after the World War I. In Brazil, the trend break occurred in the mid-1930s. We have argued that, apart from the impact of de-globalization on relative factor price movements, a difference in economic and social policies may explain this gap in timing.

All three countries reached a labor income share peak in the early postwar era, but it was in the 1950s in Argentina, the early-1960s in Brazil and the mid-1970s in Mexico. This is the period during which ISI policies prevailed throughout Latin America. Labor income shares appeared to respond to the intensity of these policies, for instance, during the Péron government in Argentina (1946-1955). This is an important result as it offers additional support for the view that income inequality was substantially lower and living standards were improving rapidly during the mid- $20^{\text {th }}$ century. The timing of the major turning points in the labor income share coincided with political regime changes and ensuing economic policy reforms. The crucial economic reforms were often taken under pressure of macro-economic instability and financial crises. The decline in the labor income share in the last quarter of the century was noticeable in all three countries, but in Argentina an important recovery occurred during the 1990s.

${ }^{6}$ The national income distribution Ginis of Argentina is notoriously weak. These figures were taken from various sources as listed in the UNU-WIDER (2008), World Income Distribution Database, version 2.0c: http://www.wider.unu.edu/research/Database/en_GB/database/ (accessed on April 21, 2009). The Brazilian and Mexican figures are from ECLAC (2005, Table 1.6.4, p. 79). See also Astorga et al. (2005) and Prados de la Escosura (2005), who underline the view that income inequality worsened in these countries during the closing decades of the $20^{\text {th }}$ century. 
The impact of demographic growth and rural-urban migration on the expansion of the urban informal sector was much more limited in Argentina than in either Brazil or Mexico and this may explain why the decline of the labor income share was not prolonged in the former country. It was not possible to maintain the relatively high wage levels of the ISI era in any of these three countries, but the increasing pressure of a rapidly expanding urban labor force was felt much more in Brazil and Mexico. The restored openness of the Brazilian and Mexican economies to international trade only reinforced the pressure on wages in industries facing the increased international competition of low-wage countries in Asia. Indeed, the indirect impact of informal sector expansion on relative labor remunerations in Brazil and Mexico is hard to measure but can hardly be underestimated.

A final note on the limitations of our estimation procedure seems justified. The major drawback of the approach followed in this paper is that, because of a lack of suitable data, shifts in capital income distribution were not taken into account. Such shifts may have countervailed the main trends outlined above for various reasons. One of the reasons is that in the expanding urban informal economies the income derived from capital ownership may be considerable. Informal sector workers were assumed to earn a shadow wage, but their capital income has not been taken into account in our framework. This could be a reason why the declines in the labor income share observed in Brazil and Mexico had a less dramatic positive impact on the secular income inequality trend than one would expect. On the other hand, the neo-liberal reforms in Latin American economies also paved the way for the unrelentless private accumulation of capital, which had been under public control until at least the 1980s. How did these forces impact on the secular income inequality trend? The fact that we cannot really answer this question simply indicates that much more research is required to complete the picture.

\section{REFERENCES}

Arroyo Abad, A. L. (2008): «Inequality in Republican Latin America: Assessing the Effects of Factor Endowments and Trade». GPIH Working Papers no. 12.

Astorga, P.; Berges, A. R., and Fitzgerald, V. (2005): "The Standard of living in Latin America During the Twentieth Century». Economic History Review 68 (4), pp. 765-796.

BaER, W. (1984): «Brazil. Political Determinants of Development», in R. Wesson (ed.), Politics, Policies and Economic Development in Latin America. Stanford CA: Hoover Press, pp. 53-73.

Baten, J., and Manzel, K. (2009): "Convergence and Divergence of Numeracy: The Development of Age Heaping in Latin America, 17th to 20th Century. University of Tuebingen Working Paper.

BeCCARIA, L. (1991): «Distribución del ingreso en la Argentina: Explorando lo sucedido desde mediados de los setenta». Desarrollo Económico 31, pp. 319-338. 
BéRtola, L. (2005): «A 50 años de la curva de Kuznets: crecimiento económico y distribución del ingreso en Uruguay y otras economías de Nuevo asentamiento desde 1870». Investigaciones de Historia Económica 3, pp. 135-176.

Bértola, L., and Castelnovo, C. et al. (2008): «Income distribution in the Latin American Southern Cone during the first globalization boom, ca: 1870-1920». Universidad Carlos III de Madrid Working Papers in Economic History no. 08-05.

Bértola, L., and Castelnovo, C. et al. (2009): «Between the Colonial Heritage and the First Globalization Boom: On Income Inequality in the Southern Cone». XVth World Economic History Congress. Utrecht.

Bértola, L., and Williamson, J. G. (2006): "Globalization in Latin America before 1940», in V. Bulmer-Thomas, J. H. Coatsworth, and R. Cortés Conde (eds), The Cambridge Economic History of Latin America. Volume II: The Long Twentieth Century. Cambridge, Mass.: Cambridge University Press, pp. 11-57.

Bulmer-Thomas, V. (2003): The Economic History of Latin America since Independence. Cambridge, U.K.: Cambridge University Press.

Cardoso, E., and Helwege, A. (1992): Latin America's Economy. Diversity, Trends, and Conflicts. Cambridge, Mass.: The MIT press.

Cortés Conde, R. (2006): «Fiscal and Monetary Regimes», in V. Bulmer-Thomas, J. H. Coatsworth, and R. Cortés Conde (eds), The Cambridge Economic History of Latin America: The Long Twentieth Century, vol. II. Cambridge, Mass.: Cambridge University Press, pp. 209-248.

De Ferranti, D., and Perry, G. E., et al. (2004): Inequality in Latin America. Breaking with History? Washington, D.C.: World Bank.

De Janvry, A., and Sadoulet, E. (2002). «Land Reforms in Latin America: Ten Lessons toward a Contemporary Agenda». Paper presented at the World Bank's Latin American Land Policy Workshop, June 14, 2002.

De Vries, G., and Timmer, M. P. (2007): «A Cross-country database for sectoral employment and productivity in Asia and Latin America, 1950-2005». University of Groningen GGDC-Research Memorandum GD-94.

ECLAC (2005): Statistical Yearbook for Latin America and the Caribbean, 2005. Santiago de Chile: ECLAC.

Edwards, S. (1995): Crisis and Reform in Latin America. From Despair to Hope. Washington, D.C.: World Bank, Oxford University Press.

Frankema, E. H. P. (2009a): "The Expansion of Mass Education in Twentieth Century Latin America: A Global Comparative Perspective». Revista de Historia Económica 27 (3), pp. 359-395.

Frankema, E. H. P. (2009b): Has Latin America Always Been Unequal? A comparative study of asset and income inequality in the long twentieth century. Leiden, Boston: Brill.

Frankema, E. H. P. (2010): «The Colonial Roots of Land Inequality: Geography, Factor Endowments or Institutions?». Economic History Review 63 (2), pp. 418-451.

Galiani, S., and Gerchunoff, P. (2003): «The Labor Market», in G. della Paolera, and A. M. Taylor (eds), A New Economic History of Argentina. Cambridge, Mass.: Cambridge University Press.

Gereffi, G., and Evans, P. (1995): «Transnational Corporations, Dependent Development, and State Policy in the Semiperiphery: A Comparison of Brazil and Mexico", in J. L. Dietz (ed.), Latin America's Economic Development. Confronting Crisis. Boulder, C.O.: Lynne Rienner, pp. 203-236.

Hanson, R. D. (1971): The Politics of Mexican Development. Baltimore, M.D.: The Johns Hopkins University Press. 
Huber, E., and SAFFord, F. (eds) (1995): Agrarian Structure and Political Power. Landlord and Peasant in the Making of Latin America. Pittsburgh, P.A.: University of Pittsburgh Press.

Hussmanns, R. (2004): "Measuring the Informal Economy: From Employment in the Informal Sector to Informal Employment». ILO ILO Policy Integration Department Working Paper no. 53.

ILO (1993): Statistics of Employment in the Informal Sector. Report of the XVth International Conference of Labour Statisticians, 19-28 January. Geneva: ILO.

ILO (1997): Economically Active Population 1950-2010. Geneva: International Labour Organization.

ILO (2006): Key Indicators of the Labour Market 2006. Geneva: ILO.

ILO: Yearbook of Labour Statistics. Various issues 1936-2005. Geneva: ILO.

Kuznets, S. (1955): «Economic Growth and Income Inequality». The American Economic Review 45, pp. 1-28.

Kuznets, S. (1966): Modern Economic Growth. Rate, Structure and Spread. New Haven, C.T.: Yale University Press.

Levine, R. M. (1999): The History of Brazil. New York: Palgrave Macmillan.

Levy, D. C.; Bruhn, K., and Zebadúa, E. (2006): Mexico. The Struggle for Democratic Development. Berkeley, C.A.: Univeristy of California Press.

Lewis, C. M. (1986): «Industry in Latin America before 1930», in L. Bethell (ed.), The Cambridge History of Latin America, c.1870 to 1930, vol. IV. Cambridge, Mass.: Cambridge University Press, pp. 267-324.

Lewis, P. H. (1990): The Crisis of Argentine Capitalism. Chapel Hill, N.C.: University of North Carolina Press.

Lewis, W. A. (1954): «Economic Development with Unlimited Supplies of labor». The Manchester School of Economic and Social Studies 22, pp. 139-191.

Lindert, P. H. (2000): "Three Centuries of Inequality in Britain and America», in A. B. Atkinson, and F. Bourguignon (eds), Handbook of Income Distribution, vol. 1. Amsterdam: Elsevier North-Holland, pp. 167-216.

Maddison, A. (2003): The World Economy: Historical Statistics. Paris: OECD.

Mariscal, E., and SoKolofF, K. L. (2000): «Schooling, Suffrage, and Inequality in the Americas, 1800-1945», in S. Haber (ed.), Political Institutions and Economic Growth in Latin America. Essays in Policy, History, and Political Economy. Stanford. C.A.: Hoover Insitution Press, Stanford University, pp. 159-217.

Milanovic, B.; Lindert, P. H., and Williamson, J. G. (2008): «Measuring Ancient Inequality». NBER Working Paper no. 13550.

Morley, S. (2001): The Income Distribution Problem in Latin America and the Caribbean. Santiago de Chile, UN: ECLAC.

Morrisson, C. (2000): «Historical Perspectives on Income Distribution: The Case of Europe», in A. B. Atkinson, and F. Bourguignon (eds), Handbook of Income Distribution. Amsterdam: Elsevier North-Holland, pp. 217-260.

Mulder, N. (1999): The Economic Performance of the Service Sector in Brazil, Mexico and the USA. A Comparative Historical Perspective. Groningen: GGDC, Univeristy of Groningen.

Navarette, I. M. D. (1960): La distribución del ingreso y el desarollo económico de Mexico. Mexico, D.F.: Instituto de Investigaciones Económicas, Escuela Nacional de Economia.

O'Rourke, K., and Williamson, J. G. (1999): Globalization and History. The Evolution of a Nineteenth-Century Atlantic Economy. Cambridge, Mass.: The MIT Press.

Prados de la Escosura, L. (2005): "Growth, Inequality and Poverty in Latin America: Historical Evidence, Controlled Conjectures». Universidad Carlos III de Madrid Working Papers in Economic History no. 05-41. 
PREALC (1982): Mercado de Trabajo en Cifras.1950-1980. Santiago de Chile: ECLAC: Programa Regional de Empleo para América Latina y el Caribe.

Rosado, D. L., and Noyola, J. F. (1951): «Los Salarios reales en Mexico, 1939-1950». El Trimestre Económico 18, pp. 201-209.

Soltow, L., and van Zanden, J. L. (1998): Income and Wealth Inequality in the Netherlands, 16th-20th Century. Amsterdam: Het Spinhuis.

Sturmthal, A. (1955): «Economic Development, Income Distribution, and Capital Formation in Mexico». Journal of Political Economy 63 (3), pp. 183-201.

TCB and GGDC (January 2009a): 10-sector Database, The Conference Board and the Groningen Growth and Development Centre, available at www.ggdc.net.

TCB and GGDC (January 2009b): Total Economy Database (TED), The Conference Board and the Groningen Growth and Development Centre, available at www.ggdc.net.

Thorp, R. (1998): Progress, Poverty and Exclusion. An Economic History of Latin America in the Twentieth Century. New York: Inter-American Development Bank, The Johns Hopkins Univeristy Press.

UN (2008): World Population Prospects: The 2008 Revised Population Database, available at www.esa.un.org/unpp/.

UNU-WIDER (2008): World Income Distribution Database, Version 2.0c, available at http://www.wider.unu.edu/research/Database/en_GB/database/.

Wegenast, T. (2009): «Of Latifundia and Coronéis: Agrarian Structure and Educational Inequalities in Brazil». Working Paper Prepared for Presentation at the MiniConference "A Comparative Approach to Inequality and Development: Latin America and Europe» May 8-9.

Williamson, J. G. (1998): «Real Wages and Relative Factor Prices in the Third World 1820-1940: Latin America». Harvard Institute of Economic Research Discussion Paper no. 1853.

Williamson, J. G. (1999): «Real Wages, Inequality and Globalization in Latin America before 1940». Revista de Historia Económica 17 (Número especial), pp. 101-142.

Williamson, J. G. (2002): «Land, Labor and Globalization in the Third World 18701940 ». Journal of Economic History 62 (1), pp. 55-85.

WorldBank (2006): Equity and Development. World Development Report 2006. Washington, D.C.: World Bank.

WorldBANK (2008): World Development Indicators 2008. Washington, D.C.: World Bank.

\section{APPENDIX}

\section{TABLE A1: DESCRIPTION OF SOURCES USED IN SECTIONS 4 AND 5}

Labor force data: Argentina: for 1913-1984 from Instituto de Estudios Económicos Sobre la Realidad Argentina y Latinoamericana (IEERAL 1986), Estudios. Estadisticas de la evolución económica de Argentina, 19131984, extrapolated for 1985-2000 with economically active population (EAP) figures from the World Bank, World Development Indicators 2003 obtained from Oxlad. Brazil: 1940 from UN Statistical Yearbook 1948, 1950 from ILO, Laborsta (2002), http://laborsta.ilo.org/, and for 1960-2000 from the World 
Bank, World Development Indicators 2003, all figures obtained from Oxlad; for 1920-1940 figures were extrapolated on the basis of population data from Wilkie, J.W., Statistical Abstract of Latin America 2002, obtained from Oxlad and for the years 1941-1949 and 1951-1959 figures were interpolated (nonlinear growth trend). Mexico: for 1895-1959 from the Instituto Nacional de Estadistica Geografia e Informatica (INEGI 1990), Estadísticas Históricas de México, and for 1960-2000 from the World Bank, World Development Indicators 2003, obtained from Oxlad. General: the procedure for estimating the labor force share of the urban informal sector is explained in section 3. The informal sector share estimates are based on data provided by the ILO, Yearbook of Labour Statistics, various issues between 1936-2005 complemented by data from PREALC (1982)Mercado de Trabajo en Cifras. 19501980. Originally, these data stem from three different types of sources, that is, national census reports, household surveys and labor force sample surveys. Official estimates were excluded from the sample since they do not provide a consistent conceptual basis for the construction of time-series. The data are exclusively derived from sources referring to the total EAP of the age 10-16 years and above. In addition, the labor force had to be classified according to main economic sector. Hence, surveys excluding (parts of) the rural population were excluded. The reliability of the labor force data (in terms of total coverage) has been checked with the use of ILO estimates of the total EAP. Deviations were only allowed within a maximum range of 5 per cent. Labor force sample surveys were often excluded because of significant underestimation of the total labor force. One of the major sources of incompatibility between countries relates to the way unemployment is classified. Sometimes the unemployed are listed in the category «employees or wage earners», sometimes they are classified as «status unknown" or «unemployed». This classification difference does not affect the computation of the own-account workers share as long as both groups are included as part of the total labor force.

Wage data: Argentina: average rural wage 1913-1984, average urban private sector wage 1913-1984 and average public sector wage from IEERAL 1986, Estudios. Estadisticas de la evolución económica de Argentina, 1913-1984. For 1997, rural wage approximated by average wage of an asalariado in the North East region of Argentina, obtained from the Instituto Nacional de Estadistica y Censos (INDEC), Encuesta Nacional de Gastos de los Hogares 1996-1997. Urban private sector wage for 1985-1990 extrapolated with average wage of urban industrial worker from the INDEC, Anuario Estadistico de la Republica Argentina and for 1991-2000 from ILO Yearbook of Labor Statistics. Backward extrapolation for 1870-1913 with Williamson's (1999) urban unskilled wage - GDP per capita index figures. Average public sector wage for 19841988 extrapolated with average public sector wage from the INDEC, Anuario Estadistico de la Republica Argentina. Brazil: for 1934-1998 urban minimum 
FIGURE A1

COMPARATIVE DEVELOPMENT OF LABOR PRODUCTIVITY IN TRADE AND OTHER SERVICE SECTORS: ARGENTINA, BRAZIL, MEXICO AND THE UNITED STATES, 1950-2000

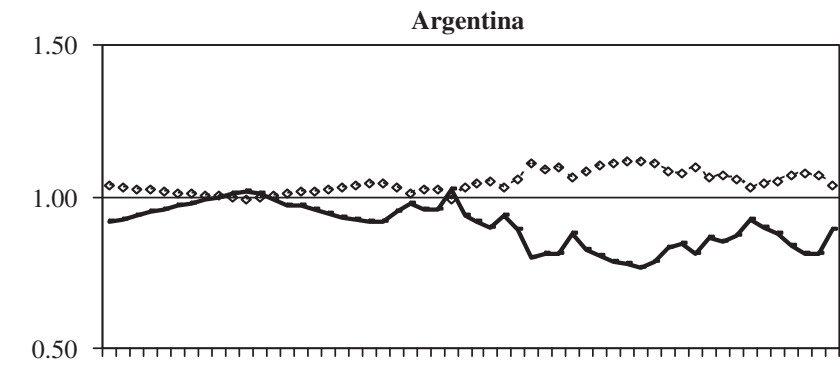

$\begin{array}{lllllllllll}1950 & 1955 & 1960 & 1965 & 1970 & 1975 & 1980 & 1985 & 1990 & 1995 & 2000\end{array}$

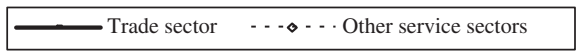

Brazil

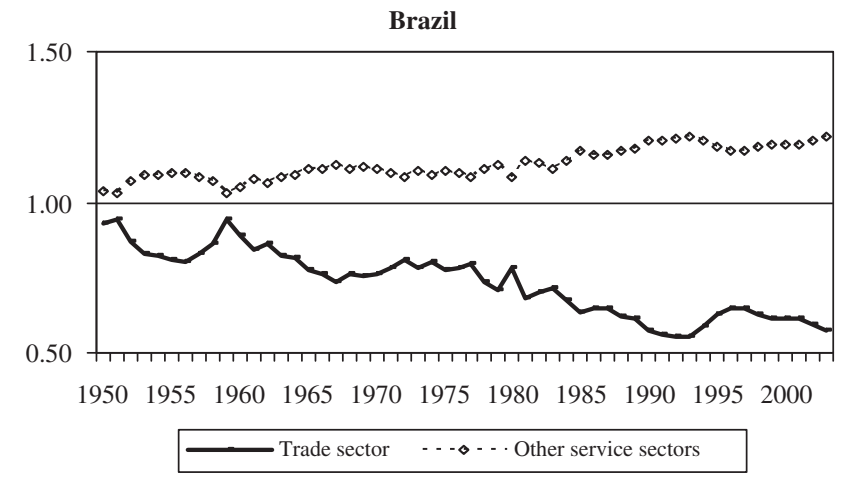

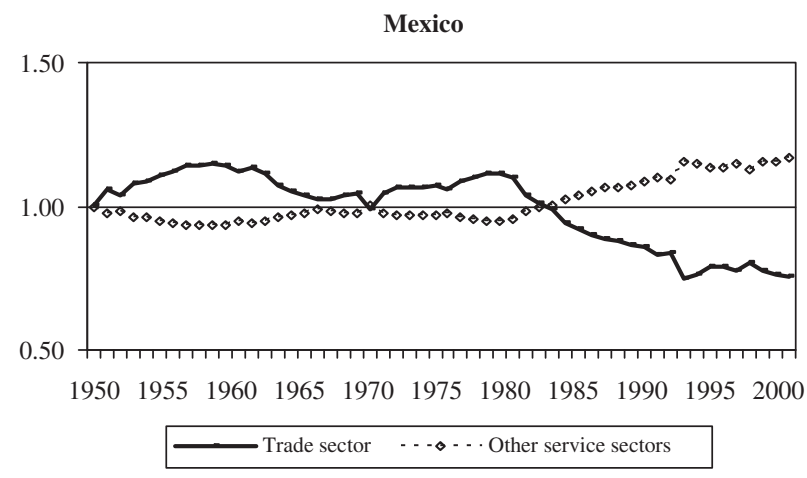

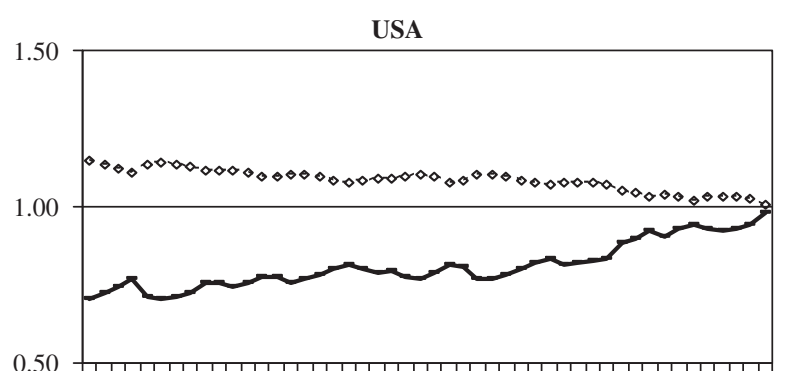

$\begin{array}{llllllllll}1950 & 1955 & 1960 & 1965 & 1970 & 1975 & 1980 & 1985 & 1990 & 1995\end{array}$

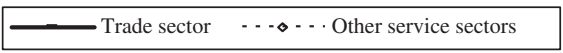


wages in Rio de Janeiro and Fortaleza (Ceará) from the Instituto Brasileiro de Geografia e Estatística (IBGE), Anuário Estatístico do Brasil. Backward extrapolation for 1904-1934 with Williamson's (1999) urban unskilled wage - GDP per capita index figures. Average manufacturing sector wage for 1939-1984 from UN, Yearbook of Industrial Statistics and IBGE Anuário estatístico do Brasil (various issues), extrapolated for 1985-2000 with manufacturing wages from ILO, Yearbook of Labour Statistics. For 1920 and 1928 figures obtained from Recenseamento do Brazil 1920, vol. V. Mexico: Rural unskilled wages for 1985-1911 and 1920-1933 from Estadisticas Historicas de Mexico, Tomo I, Salarios, for 1935-1967 from Anuario Estadistico de Estados Unidos Mexicanos, for 1968-1991 from ILO, Yearbook of Labour Statistics and for 1991-2000 extrapolated on the basis of the official minimum wage trend from Burr, R.N. and Fitzgibon, R.H. (eds) Statistical Abstract of Latin America. Urban minimum wage for 1895-1910 from Estadisticas Historicas de Mexico, Tomo I, Salarios, for 1934-1972 from Pontones, E. (1976) La Migracíon en México, in: J.W. Wilkie, M.C. Meyer and E.M. de Wilkie (eds) Contemporary Mexico, Berkeley: University of California Press, and for 1973-2000 from Burr, R.N. and Fitzgibon, R.H. (eds), Statistical Abstract of Latin America. Backward extrapolation for 1880-1935 with Williamson's urban unskilled wage - GDP per capita index figures (Williamson 1999). Average manufacturing sector wages for 1940-2000 from UN, Yearbook of Industrial Statistics, for 1930 from Primer Censo Industrial de 1930, and for 1923-1928 based on the average wages of textile workers presented in the Anuario Estadistico de Estados Unidos Mexicanos 1930. Average private sector wage for 1980-2000 from INEGI, Anuario Estadistico de Estados Unidos Mexicanos.

GDP data: Argentina: for 1913-1982 from the IEERAL (1986), Estudios. Estadisticas de la evolución económica de Argentina, 1913-1984, extrapolated for 1983-2000 with GDP figures from the IMF Yearbook of International Financial Statistics obtained from the Oxford Latin American Economic History Database http://oxlad.qeh.ox.ac.uk/; Brazil: for 1920-1961 from Mitchell (1993) and for 1962-2000 from the IBGE (1990), Estatísticas Históricas do Brasil, both series obtained from Oxlad; Mexico: for 1895-1987 from the INEGI (1990), Estadísticas Históricas de México, and for 1988-2000 from IMF Yearbook of International Financial Statistics, the latter obtained from Oxlad (Figure A1). 